All roads lead to...

Options and variations in acquiring native proficiency in Hungarian Judit H. Ward (Rutgers University) and Sylvia Clark (St. John's University)

\begin{abstract}
This paper describes a case study conducted with a first generation American heritage learner of Hungarian in a college setting. We have found our study important for several reasons. The latest developments in technology made a variety of new learning environments available, which are used mostly by the new generation of language learners. As a result, instructors are expected to accommodate a variety of learning styles. Are there appropriate resources for the learners of Hungarian, including courses, instructors, textbooks and other learning material? Can they meet the needs of the different generations of language learners with evolving new learning styles?
\end{abstract}

\title{
Background
}

Research on second language learning and teaching has been conducted from multiple perspectives, such as applied linguistics, methodology, processes and development, or curricula, to mention a few (Hinkel). Second language acquisition (SLA) is an extremely large but well studied area. There have been several books and studies written on the particular group of learners this study focuses on, i.e. bilingual students, many from a sociolinguistic perspective (e.g. Grosjean, Wardhaugh). Valdes (Bilingualism) argues that this term might be used in a restricted sense and she outlines a much broader sense. Bilingual language learners are recently also called heritage learners.

A good working definition is provided by Draper and Hicks, referring to someone "who has had exposure to a non-English language outside the formal education system" (19), most often someone with a second language spoken at home. The language characteristics and needs of heritage learners show a wide variety based on the generation (newly arrived vs. US-born and raised), schooling and academic skills in English (Valdes, Teaching).

There has also been plenty of research on American Hungarians; some areas are extensively studied, and the American Hungarian Educators' Association has played an important role. There have been only a few studies on the language of the American Hungarians (Bako, Goals and Methods, Fishman, Kontra, Bako, Az Amerikai, Bartha, Fenyvesi). However, several authors agree that language maintenance is key to preserving the Hungarian culture outside Hungary (Nagy, Vardy, Tarjan, Az unokák, Tarjan, A Nyugati, Ward and Agocs).

Even fewer studies describe and analyze factors that play a significant role in achieving near-native proficiency either as a heritage or L2 learner, especially in the writing skills to the same level. Also, Hungarian as a less commonly taught language is not widely studied. The research questions for this study can be formulated as follows: How can a Hungarian heritage language learner a become balanced bilingual and achieve the level of the near-native proficiency of the educated speaker in all four skills at this level: speaking, listening, reading, and writing? 
What are some personal preferences in language learning strategies that may contribute to it, and what is the role of the family, the extended family and the community at large?

\section{Hungarian in the United States}

Over 1.5 million people reported Hungarian ancestry in the 2002 census data in the United States, which includes 1.4 percent of the population of New Jersey. According to the 2003 American Community Survey Summary Tables, 89,792 persons reported speaking the Hungarian language at home (US Census).

Hungarian immigrants arrived in the United States in several waves starting from the end of the $19^{\text {th }}$ century. The history and issues of Hungarian immigration have been well studied and documented (Puskas, Emigration, Puskas, From Hungary, Puskas, Ties that Bind).

\section{Theoretical background}

The theoretical background of the research is rooted in the constructivist learning theory. According to this perspective, students rely on their experience and prior knowledge while they apply new concepts that they learn in the course to construct new knowledge. The new technology-based instructional applications provide an environment permitting more learner choices. Students have the chance to identify their own learning needs and make appropriate use of the available resources in a virtually unlimited learning environment (Bloxham and Armitage).

The learner's role has been changing from a passive-receptive learner to a more active one, in which students take more responsibility in their own learning. Learning from mistakes is encouraged (Gillespie). Learner success is highly related to the maintenance of motivation, levels of task engagement, and specific informationprocessing habits. In addition, the instructor should be prepared to encourage individuality and foster diversity in a virtual learning environment by accommodating a variety of learning styles, and to provide guidance but allow freedom at the same time (Porter).

\section{The research}

In the present study the researcher is the instructor, and the informant-participant is the student. They share some similarities in terms of age, educational background, values, and interests. The variety of their interactions throughout the entire five years of the research provides rich, in-depth data on learning and teaching Hungarian as a second language in an academic setting in North America.

The case can be labeled as a success story of a Hungarian heritage learner, a firstgeneration American in a unique language-learning environment of a large state university surrounded by a sizable Hungarian community. The improved language skills have also been confirmed by the highest level Hungarian language proficiency exam. The objective is to explore and describe the most important contributing elements by focusing on personal, educational, socioeconomic and family background and the nature and role of the different learning environments. 


\section{The setting: The Hungarian Program at Rutgers}

Rutgers, the State University of New Jersey in New Brunswick, features strong connections to Hungarian culture. Rutgers has supported undergraduate studies in Hungarian for over forty years. Besides Indiana University, which offers a Hungarian major, Rutgers is the only other institution with a degree program in the United States. Its Hungarian minor offers over fifteen courses on Hungarian culture and Hungarian as a second language. The Institute for Hungarian Studies contributes to the instructional and extracurricular content of the European Studies major, participates in joint research projects of the two countries in several areas, and fosters immediate contacts with Hungarian institutes of higher education. With its public lecture series, it also shapes the large Hungarian community in the New Brunswick area. Many students at Rutgers are those of Hungarian descent from the area, thus they have various levels of proficiency of the Hungarian language (Hajnal-Ward, Hajnal Ward and Clark, Culture Contacts).

\section{Data collection}

Multiple methods of data collection included open-ended observations, formal and informal interviews (written and oral), and a variety of documents throughout a period of five years. Observation was chosen as a convenient method in the given setting, since the researcher had the chance to follow the participant's advancement in a classroom setting as a participant-observer. Documents included class notes, course papers, individual and group projects, emails to the instructor, notes and log files of projects on which the researcher and the participant collaborated, and ad hoc discussions on many subjects.

Several informal conversational interviews were conducted to take advantage of the trust built among the participant, her family, and the researcher throughout the entire five years of the research. There was a formal written interview with the participant after the conclusion of her studies and completion of the proficiency exam, which aimed at placing her achievements in a wider perspective in her life in terms of her motivation, goals, and plans.

\section{Sylvia, the heritage language learner}

The main participant-informant in the study is Sylvia, a female heritage learner of Hungarian descent in her mid-40s at the beginning of the research. She was born in the United States to Hungarian 56-er immigrants and she has been exposed to the Hungarian language in a variety of settings throughout her life. Her family and educational background also includes experience with learning other languages. She is professor of marketing at a prestigious private university, and an accomplished scholar herself. She voluntarily and willingly contributed to the research study.

\section{Family background: language and education}

Sylvia was born in the United States to a pair of political émigrés three years after their relocation to the new country from socialist Hungary. They came to the United States with the wave of immigrants after the 1956 Hungarian Revolution was defeated. The mother studied to be an opera singer in Hungary. She stayed somewhat close to her original career and became a music teacher in the U.S., while the father had to give up his 
profession as a lawyer, making a career change to become a librarian. They didn't speak or learn English before arriving in the U.S., but both were exposed to other foreign languages. The mother has good knowledge of French, German, and Italian, while the father speaks German. It should be noted that they divorced, and she was reared by her mother alone from age ten.

The parents' language used at home was Hungarian; however, they both worked long hours to settle down and establish their careers in the new country. A British woman took care of the toddler, so Sylvia's first language was English, with a British accent. The parents were constantly arguing over whether the child should learn Hungarian, like many new immigrant families. The arguments for speaking only English can be explained by the fact that these were the first few years for them in the new country, and struggling with English themselves, they wanted the daughter to have a good command of the language. Her father was especially concerned about language interference at an early age. However, the language used in the family home between the parents remained Hungarian, so Sylvia was exposed to the language at home until her parents separated. The mother insisted that the child must learn Hungarian. The parents got divorced when Sylvia was ten, at which point her mother was able to bring this goal to fruition.

\section{Learning Hungarian as a child}

The first time that Sylvia recalls receiving structured instruction in Hungarian was when the mother's parents came to visit. They didn't speak English at all when they met the 9-year-old granddaughter. This language learning opportunity was followed by many, some in the United States others in Hungary. As a young child and teenager, she had the chance to visit relatives in Hungary with her father, which was a true cultural awakening for the child. The family reunions in the old country seem to have served as a great motivation later on, with interest in the Hungarian language and culture definitely present as early as that.

As a child, peer support and peer pressure also played a role in improving her knowledge of the language, whether among American-Hungarian or Hungarian children or teenagers. Intensive language learning periods were parts of Sylvia's early years toward improving her language proficiency.

By this time, the parents more or less had agreed that she should pursue this path. A unique opportunity to learn the language was also afforded Sylvia in her mid-teens: she completed her third year of high school at Veres Pálné gimnázium in Budapest. The complete time line of her childhood Hungarian language learning experiences is shown in Table 1.

\begin{tabular}{|l|l|}
\hline ongoing & Parents always spoke Hungarian to each other \\
\hline 1968 & $\begin{array}{l}\text { Grandparents' visit from Hungary, they spoke only Hungarian, } \\
\text { the grandfather taught her from books }\end{array}$ \\
\hline 1970 & $\begin{array}{l}\text { Sylvia's visiting relatives with her father in Pécs, Hungary, no } \\
\text { one speaks English }\end{array}$ \\
\hline 1972 & 8-week intensive Hungarian language camp in Ligonier, PA \\
\hline
\end{tabular}




\begin{tabular}{|l|l|}
\hline 1973 & $\begin{array}{l}\text { 4-week intensive Hungarian language camp in Fonyódliget, } \\
\text { Hungary, taught by native speaker-teachers }\end{array}$ \\
\hline 1974 & 2-week in the same camp Fonyódliget, Hungary \\
\hline 1974 & $\begin{array}{l}\text { 4-week intensive advanced-level Hungarian language camp in } \\
\text { Sárospatak, Hungary, specifically designed for heritage } \\
\text { learners, also taught by native speaker-teachers }\end{array}$ \\
\hline $1974 / 75$ & $\begin{array}{l}\text { Academic year in Hungary, third year of high school at Veres } \\
\text { Pálné gimnázium in Budapest }\end{array}$ \\
\hline
\end{tabular}

Table 1. Timeline of Sylvia's exposure to the Hungarian language as a child

\section{Experience with other languages}

Sylvia's career took the direction of business in her college years; however, she never abandoned languages. She was able to squeeze in some language courses into her busy schedule, no matter what the main focus of her life was. Her experience with learning foreign languages includes French, Latin, German, Italian, and Spanish. All the language learning experiences took place in a structured classroom setting, indicating Sylvia's preference of learning languages. She argues that classroom instruction, possibly with a native speaker language teacher, is the most successful way to learn languages.

\section{Learning Hungarian at Rutgers}

The Rutgers years proved to be a turning point in reaching near-native proficiency in Sylvia's language learning. She enrolled in the first course, Hungarian Culture Today, taught in English, in the spring semester 1999. It was her mother who strongly encouraged Sylvia to try out the Hungarian program at Rutgers. Sylvia was back to school again, taking courses with undergraduates, many of them half of her age, but with a fraction of her enthusiasm and motivation. She was fluent in Hungarian with the large vocabulary of an educated speaker, and had some knowledge of Hungarian grammar at that time, but she still felt she had a lot to learn.

\section{The learning environment: Personal components}

A series of lucky encounters started with meeting Zsuzsi, another student of Hungarian descent the same age as Sylvia. Zsuzsi was less fortunate in terms of being exposed to the language. As a child, she had spoken fairly well, together with her sister, Ági. However, the daily routine and the English-only environment dominated. Zsuzsi did not enjoy the same level of parental support, and had not been exposed to any of the structured childhood and adolescent learning experiences from which Sylvia had profited. The two student-friends supported each other throughout the entire program.

Sylvia was further supported by the incoming visiting professor in 1999, Judit, who had a background in applied linguistics, instructional design and various second language teaching methodologies. Her experience also included teaching Americans and other heritage learners, as well as fostering a variety of learning styles for multicultural language learners. During the four years at Rutgers a special learning environment was created which included face-to-face and virtual settings, a variety of learning resources matching students' interests, a variety of teaching tools, and well-defined learning 
outcome and tangible goals for each period, such as the Hungarian Language Proficiency Exam.

\section{The learning environment: Classroom and extracurricular activities}

The face-to-face learning environment included informal meetings and Hungarian functions in addition to the formal class setting at Rutgers. Sylvia took all possible classes offered in Hungarian at and above the 300-level, as shown in Table 2.

\begin{tabular}{|l|l|}
\hline 259 & Hungarian Civilization \\
\hline 260 & Hungarian Culture Today \\
\hline 301 & Conversational Hungarian \\
\hline 321 & Hungarian Poetry \\
\hline 355 & Translation \\
\hline 402 & Advanced Writing Workshop \\
\hline 403 & Advanced Internship \\
\hline 490 & Hungarian Literature Seminar \\
\hline 493 & Independent Study \\
\hline 494 & Independent Study \\
\hline
\end{tabular}

Table 2 Hungarian courses Sylvia took at Rutgers. Her GPA is 4.0

She also completed an advanced course in writing, grammar, and stylistics offered at the American Hungarian Language Center. This course was subsequently accredited at Rutgers as Hungarian 401. By the conclusion of the courses, and before taking the Hungarian language proficiency exam, Sylvia was confident that her skills had improved significantly. Extracurricular activities at Rutgers featured open classes, to which parents and siblings were invited, competitions, movie screenings, field trips, parties, sporting events, and even a students conference.

\section{The virtual learning environment}

The virtual learning environment consisted of various forms of online communication: emails and a Hungarian grammar listserve, document and resource sharing, and plenty of links to information on the instructor's web site. The installation of the Hungarian keyboard for all written communication was a milestone, since it is essential to improving writing skills. The virtual learning environment also utilized online course management systems, such as WebCT and the Rutgers online language learning environment known as Digiclass (Hajnal Ward). Another virtual learning environment was sponsored by the Fulbright Foundation for two years (Clark and Ward, Culture Contacts without Borders). Culture Contacts was an online experimental project that we presented at the AHEA Conference in 2003 (Clark and Ward, Culture Contacts). Sylvia moderated the forum, which was only one of her great contributions to the project.

\section{Results: improving language proficiency}

Sylvia's improvement can be hallmarked by a few milestones in the past five years. Not only did she excel in every class she took, but the example she set was 
contagious. Heritage learners of Hungarian at Rutgers felt motivated to take more courses, especially ones in order to improve their writing skills and to learn Hungarian grammar, which eventually resulted in the introduction of four new courses to the Hungarian minor. Sylvia was the first student who qualified to participate in an advanced level internship. As an intern, she contributed to the daily teaching activities of Hungarian 102, including classroom instruction, lab practices, creating quizzes, and grading. Some other major achievements include winning all possible awards and contests in the Program at Rutgers, teaching Elementary Hungarian and conducting her own research in Hungarian.

When she was asked to give examples of some activities she feels more comfortable doing after completing all these courses at Rutgers, Sylvia noted the following:

Reading in Hungarian: Because of all the practice in class, I feel much more comfortable reading other materials in Hungarian on my own. On a recent trip, I purchased popular Hungarian-language books and breezed through them without a dictionary.

Writing e-mails: Thanks to my Hungarian keyboard coupled with my increased knowledge of spelling and grammar, composing e-mails to my friends and relatives has become much easier.

Conversing at conferences: At both AHEA conferences and the Hungarian Congress in Cleveland, I am much more at ease, even in discussing fairly technical subjects.

Conducting research: In my own professional research, including composing surveys and holding interviews, I am better able to communicate.

\section{The instructor's evaluation}

The instructor has found astonishing the improvement in Sylvia's language proficiency over the four years at Rutgers chiefly a significant decrease in the number of errors in the written samples, e.g. grammatical errors can be found only very infrequently in the later texts. A shift of the type of errors in the later texts is noticeable from grammatical errors to small and sophisticated nuances in language use.

An outstanding student in terms of work ethic, Sylvia never missed a class or a deadline, her class notes were exemplary, and she took every opportunity to learn a new word, phrase, or usage. She would write down every single word or phrase with which she was unfamiliar in the particular context, ensuring that she understood the meaning and context perfectly by asking questions in or after class. She was always willing to help others and work in pairs or in small groups on class projects. Sylvia was always the first to volunteer if the syllabus called for a project, a presentation, or any out-of-class activity, for all the inconveniences she had to encounter while driving a considerable distance to the classes two or three times a week. Many of her class projects are of such high quality that they could be used as examples or for teaching Hungarian culture. Some were even published in Hungarian and American Hungarian newspapers, such as interviews, translations, and summaries (e.g. Hajnal, Hungarian Program, Clark and Ward, Culture Contacts, etc.). She is a true role model for other heritage learners.

\section{Results: The advanced language proficiency exam}

The most tangible result was passing the very challenging Hungarian State Proficiency Exam at the advanced level with flying colors (Table 3). The Hungarian State 
Proficiency exam (also known as the ORIGO test system) tests four skills (reading, listening, writing, and speaking) at beginner, intermediate, and advanced levels. It was designed, and has been conducted by the Centre for Advanced Language Learning, Budapest, Hungary, a member of the prestigious Association of Language Testers in Europe. The exam was first offered in the United States in 2002, and Sylvia was the first candidate. Her oral proficiency exam was administered by the Director and Associate Director of the ORIGO Language Proficiency Systems visiting from Hungary for the occasion of opening the center. This type of certificate of language proficiency is extremely prestigious in Europe, where it serves to fulfill the rigorous language requirements of college entrance exams or degrees, depending on the level.

\begin{tabular}{|l|l|l|l|}
\hline ORAL EXAM & Maximum & Score & \\
\hline Communication & 20 & 18 & \\
\hline Vocabulary & 20 & 16 & \\
\hline Use of the language & 20 & 14 & \\
\hline Listening comprehension (human) & 5 & 5 & \\
\hline Listening comprehension (recorded) & 25 & 19 & \\
\hline TOTAL & 90 & 72 & $86 \%$ \\
\hline WRITTEN EXAM comprehension & 20 & Score & \\
\hline Grammar and usage test & 20 & 16 & \\
\hline $\begin{array}{l}\text { Reading } \\
\text { interpretation }\end{array}$ & 20 & 18 & \\
\hline Threaded composition & 20 & 17 & \\
\hline Reading comprehension test & 80 & 18 & \\
\hline TOTAL & & 69 & $80 \%$ \\
\hline
\end{tabular}

Table 3. Sylvia's grades on the advanced level Hungarian language proficiency exam. The maximum is $100 \%$, virtually unheard of, while the passing grade is $60 \%$.

The exam at the advanced level comprises a four-hour written segment, including a 50question multiple choice grammar test, two types of reading comprehension, and a guided composition. The oral segment has a free conversational part, a discussion based on pictures, a situational dialogue, and a listening comprehension part based on a prerecorded text, carefully designed and tested by the Center.

\section{Conclusions}

The case study of a bilingual heritage speaker of Hungarian has revealed some patterns in the language learning behavior of the adult student. According to Romaine's typology of bilingual acquisition in childhood, Sylvia is a Type 3, i.e. 'non-dominant home language without community support', where the parents' language is not the dominant language of the community. The parents used Hungarian with the child, so did the members of the extended family; however, formal education took place in English and the language used with other children was also dominantly English. We agree with Romaine (215-216) that the language input, namely the quality of the input has the most decisive role. In Sylvia's case, the family background (including parental education 
levels and ethnic identity) has been found extremely stimulating in terms of encouragement and financial assistance from the immediate family members in the long run. Additionally, improving proficiency in the language was also motivated by the need to keep in touch with the members of the extended family, including a host of relatives in Hungary.

Childhood and young adult language acquisition and learning experiences have proven decisive for the adult learner. The pattern of learning the Hungarian language in a structured language-learning environment, i.e. in a summer camp, a course, or at school, can be recognized in the early years of learning Hungarian. Sylvia's language learning preferences and favorite activities all trace back to the same pattern as an adult. As an adult, Sylvia was able to recognize this pattern, and successfully identified her own language learning needs and preferences. She thus took the initiative to enroll in a Hungarian minor program to perfect her language skills to the desired level. Aware of her own personal learning style and preference, i.e. classroom instruction with a native speaker instructor, she took responsibility for her own learning, which also made her creative in finding the best possible sources and settings for learning.

Although Sylvia doesn't belong to the NetGen students, she was able to take full advantage of the learning options offered by emerging technologies. Our study may encourage language instructors to explore innovative learning environments and introduce them into Hungarian language acquisition, such as course management systems and evolving popular applications in the area of social networking that learners use in everyday life. We firmly believe that different leaning styles must be incorporated into curriculum development, while adding measurable goals, such as external proficiency exams, is a great motivator. 


\section{Works Consulted}

Bakó, E. Goals and Methods of Hungarian Dialectology in America. New Brunswick, NJ: American Hungarian Studies Foundation, 1962.

---. Az Amerikai Magyarok Nyelvének Kutatásáról [About the Research on the Language of American Hungarians]. Debrecen, Hungary: Bakó Magyar Népnyelvi Szótár Alapítvány, 2002.

Bartha, C. "Nyelvhasználat, Nyelvmegtartás, Nyelvcsere Amerikai Magyar Közösségekben." Tér és Terep. Tanulmányok az Etnicitás és az Identitás Kérdésköréböl. Ed. Kovács Nóra, Szarka László. Budapest, Hungary: Akadémiai Kiadó, 2002. 111-136.

Bloxham, S. and Armitage, S. (2003). "What a LUVLE Way to Learn Law." International Review of Law, Computers \& Technology 17.1 (2003) : 39.

Clark, S.C. and Ward, J.H. "Culture Contacts: An Experimental Online AmericanHungarian Project." Presentation at the Conference of American Hungarian Educators' Association. Columbia University, New York, NY. 24-25 Apr. 2003.

---. "Culture Contacts without Borders: An Experimental Online American-Hungarian Project." Proceedings of the XLIIIth Annual Conference of the Hungarian Scientific, Literary, and Artistic Association. Ed. L.F. Somogyi. Cleveland, OH: Arpad Publishing, 2004. 275-277.

Draper, B.D. and Hicks, H.H. “Where We've Been; What We've Learned.” Teaching Heritage Language Learners: Voices from the Classroom. Ed. J.B. Webb and B. Miller. New York: ACTFEL, 2000. 15-39.

Fenyvesi, A. Hungarian Language Contact Outside Hungary: Studies on Hungarian as a Minority Language. Amsterdam; Philadelphia: John Benjamins, 2005

Fishman, J. A. Hungarian Language Maintenance in the United States. Bloomington: Indiana University, 1966.

Gillespie, F. "Instructional Design for the New Technologies." New Directions for Teaching and Learning 76 (1998) : 39-52.

Grosjean, F. Life with Two Languages : An Introduction to Bilingualism. Cambridge, Mass: Harvard UP, 1982.

Hajnal, J. "The Hungarian Program at Rutgers, the State University of New Jersey." Nyári Egyetem, Newsletter of Debrecen Summer University of Hungarian Studies 2 (2000) : 4-5. 
Hajnal Ward, J. "Information Technology in Hungarian Studies: Digiclass @ Rutgers." Teaching Hungarian Language as a Second Language and Culture 2.12005 : 117125.

---. "Hungarológia a XXI. Században: Rutgers Egyetem, USA [Hungarian Studies in the $21^{\text {st }}$ century: Rutgers University, USA].” THL2 1 (2005) : 84-93.

Hajnal Ward, J and Clark, S. "Culture Contacts: An Experimental American-Hungarian Project in the Online Language-learning Environment." Proceedings of the 2nd International Online Conference on Second and Foreign Language Teaching and Research. 16-18 Sept. 2005. 79-86.

Hinkel, E., ed. Handbook of Research in Second Language Teaching and Learning. Mahwah, NJ: Lawrence Erlbaum Associates, Inc., 2005.

ITK. Idegennyelvi Továbbképző Központ. (n.d.) The Website of the Hungarian State Language Proficiency Exam ORIGO Systems. In Hungarian. Retrieved September 6, 2005 from http:www.itk.hu.

Kontra, M. "Hungarian-American Bilingualism: A Bibliographic Essay." Hungarian Studies [Hungary] 1.2 (1985) : 257-282.

Nagy, K. Magyar Szigetvilágban ma és Holnap [In a Hungarian Diaspore Now and Tomorrow]. New York: Püski, 1984.

Porter, L. R. Developing an Online Curriculum: Technologies and Techniques. Hersey, PA; London: Information Science Pub., 2004.

Puskás, J. Emigration from Hungary to the United States before 1914. Budapest, Hungary: Akadémiai Kiadó, 1975.

---. From Hungary to the United States (1880-1914). Budapest, Hungary: Akadémiai Kiadó, 1982.

---. Ties that Bind, Ties That Divide: 100 Years of Hungarian Experience in the United States. New York: Holmes \& Meier, 2002.

Romaine, S. Bilingualism. $2^{\text {nd }}$ ed. Oxford: Blackwell, 1995.

Tarján, G. "Az Unokák Visszatérnek. Nyugati Magyar Fiatalok Kollégiuma Magyarországon [The grandchildren return. Collegium of Young Western Hungarians].” Nyelvünk és Kultúránk, 109 (2000) : 40-42.

---. “A Nyugati Magyarság Jövője [The Future of Western Hungarians].” A XL. Magyar Találkozó Krónikája, Cleveland, 2001. 72-76. 
U.S. Census Bureau. Census 2000 Brief: Language Use and English-language Ability. No. C2KBR-19. Washington, DC: U.S. Census Bureau, Oct. 2003.

Valdes, G. "The Teaching of Minority Languages Academic Subjects: Pedagogical and Theoretical Challenges.” Modern Language Journal 79 (1995) : 299-328.

---. "Bilingualism, Heritage Language Learners, and SLA Research: Opportunities Lost or Seized?" Modern Language Journal 89.3 (2005) : 410-426.

Vardy, S. B. "Image and Self-image Among Hungarian-Americans Since the Midnineteenth Century." East European Quarterly 35.3 (2001) : 309

Ward, J. H., and Agócs, L. "Language Maintenance on the Internet.” Educational Media International 41.1 (2004) : 27-30.

Wardhaugh, R. An Introduction to Sociolinguistics. 5th ed. Malden, MA ; Oxford: Blackwell Pub., 2006. 